\title{
Peningkatan motivasi intrinsik dan kemampuan kognitif level anaisis melalui penerapan model pembelajaran group investigation (GI)
}

\author{
Widya Pursetianingsih ${ }^{*}$, Nani Aprilia ${ }^{2}$ \\ Program Studi Pendidikan Biologi, Fakultas Keguruan dan Ilmu Pendidikan, Universitas Ahmad Dahlan, \\ Jl. Jendral Ahmad Yani (Ringroad Selatan) Tamanan, Banguntapan, \\ Bantul, Daerah Istimewa Yogyakarta 55191 \\ 1 widyapursetianingsih10@gmail.com*; 2 nani.aprilia@pbio.uad.ac.id \\ *korespondensi penulis
}

\begin{abstract}
Abstrak
Penelitian ini bertujuan untuk mengetahui penerapan model pembelajaran group investigation (GI) dapat terlaksana sesuai dengan sintak-sintak pembelajaran, serta besarnya persentase peningkatan motivasi intrinsik dan kemampuan kognitif level analisis siswa pada materi pemanasan global dari setiap siklus.

Penelitian ini merupakan penelitian tindakan kelas (PTK), subjek penelitian adalah siswa kelas VII B SMP Negeri 2 Prambanan Sleman tahun pelajaran 2018/2019 dengan objek penelitian motivasi intrinsik, kemampuan kognitif level analisis dan model GI. Teknik pengumpulan data berupa observasi dan tes. Instrumen berupa lembar observasi motivasi intrinsik, lembar observasi keterlaksanaan pembelajaran model GI dan soal post-test pilihan ganda. Analisis data menggunakan analisis deskriptif kuantitatif.

Hasil penelitian menunjukkan bahwa dengan penerapan model GI, motivasi intrinsik dan kemampuan kognitif level analisis pada siklus I dan siklus II mengalami peningkatan. Pada siklus I rata-rata motivasi intrinsik belajar siswa $45,53 \%$ meningkat pada siklus II menjadi rata-rata 79,58\%. Rata-rata nilai post-test siswa (mencakup level ingatan, pemahaman, aplikasi hingga analisis) pada siklus I yaitu 72,14 meningkat pada siklus II menjadi 84,22. Sedangkan persentase peningkatan kemampuan kognitif level analisis pada siklus I mencapai 69,90\% meningkat jadi $80,56 \%$ pada siklus II.
\end{abstract}

Kata kunci: Group Investigation (GI), Kemampuan Kognitif Level Analisis, Motivasi Intrinsik

\section{Abstract}

The learning process in the classroom that only focuses on the teacher makes the students less motivated and gives less freedom to students to think analytically, so it is necessary to apply learning models that can increase intrinsic motivation and cognitive abilities in the level of analysis of students. This study aims to determine the application of the investigation group (GI) learning model that can be carried out according to the learning syntaxes and the magnitude of the percentage increase in intrinsic motivation and cognitive abilities in the level of analysis of students from each cycle.

This research is classroom action research (CAR) with the research subjects are students of class VII B Prambanan Sleman 2 Public Middle School 2018/2019 and the object of research is intrinsic motivation, cognitive level analysis, and GI model. Data collection techniques in the form of observation and tests. The instrument used to collect data is in the form of observation sheets for students' intrinsic motivation and multiple- 
choice post-test questions. Data analysis using quantitative descriptive analysis.

The results showed that with the application of the GI model intrinsic motivation and cognitive abilities the level of analysis of students in the first cycle and the second cycle had increased. In the first cycle, the average intrinsic motivation of student learning $45.53 \%$ increased in the second cycle to an average of $79.58 \%$. The average post-test scores of students (including memory level, comprehension, application to analysis) in the first cycle of 72.14 increased in the second cycle to 84.22. Also, the cognitive ability of the first cycle of analysis level $69.90 \%$ increased by $80.56 \%$ in the second cycle.

Keywords: Group Investigation (GI), Cognitive Ability Level Analysis, Intrinsic Motivation

\section{PENDAHULUAN}

Saat ini meskipun masalah yang berkaitan dengan proses belajar mengajar telah banyak memperoleh pemecahan, nyatanya sekarang masih banyak ditemukan permasalahan yang ada di sekolah salah satunya yaitu di SMP Negeri 2 Prambanan Sleman berkaitan dengan motivasi intrinsik belajar siswa dan kemampuan kognitif level analisis terhadap materi yang disampaikan guru belum optimal. Hal tersebut di buktikan dengan hasil observasi awal dikelas VII B SMP Negeri 2 Prambanan Sleman yang menunjukkan kesungguhan atau motivasi belajar dalam diri siswa masih kurang. Motivasi seperti ini disebut dengan motivasi intrinsik. Menurut Sardiman (2016: 89-90) bahwa motivasi intrinsik (internal), merupakan motif-motif yang aktif atau berfungsi tanpa adanya rangsangan dari luar, karena dalam diri setiap individu sudah ada dorongan untuk melakukan sesuatu, contohnya adalah seseorang yang senang membaca, tanpa ada yang menyuruh atau mendorongnya, ia sudah rajin membaca buku-buku untuk dibacanya.

Konsep motivasi intrinsik menggambarkan tingkah laku siswa terhadap sesuatu, apabila siswa menyenangi suatu kegiatan, maka siswa tersebut termotivasi untuk melakukan kegiatan tersebut. Jika siswa menghadapi tantangan dan merasa yakin dirinya mampu, maka siswa tersebut akan melaksanakan kegiatan tersebut dengan baik (Sukimarwati.,dkk, 2013: 46-57).

Adanya motivasi dari dalam diri siswa akan berakibat pada hasil belajarnya, yang mana dalam penelitian ini yaitu kemampuan kognitif level analisis. Abdurrahman, M (2012: 131) mendefinisikan kemampuan kognitif adalah proses yang terjadi secara internal di dalam pusat saraf pada waktu manusia sedang berpikir. Kemampuan kognitif berkembang secara bertahap, sejalan dengan perkembangan fisik dan saraf-saraf yang ada pada pusat susunan saraf. Kemampuan kognitif merupakan dasar bagi kemampuan anak untuk berpikir. Sehingga, proses kognitif selalu berhubungan dengan tingkat kecerdasan (inteligensi) yang 
ditandai dengan berbagai minat seseorang terutama ditujukan kepada ide-ide berpikir (Susanto, 2011: 48).

Adapun teori yang berpengaruh dalam menjelaskan perkembangan kognitif ini adalah teori Piaget. Sedangkan menurut Benyamin S. Bloom (dalam Anderson \& Krathwohl, 2010: 40) mengatakan bahwa kemampuan kognitif level analisis merupakan jenjang kemampuan kognitif yang menuntut peserta didik untuk menguraikan situasi atau keadaan tertentu ke dalam unsur-unsur atau komponen pembentuknya. Kemampuan menganalisis juga dapat diartikan menentukan bagian-bagian dari suatu masalah, dan penyelesaian atau gagasan serta menunjukkan hubungan antar bagian itu.

Kemampuan analisis siswa dapat timbul jika sering dilatih. Salah satu cara agar siswa terbiasa berpikir secara analisis yaitu dengan membiasakan siswa memecahkan masalah yang berkaitan dengan materi pembelajaran. Sehingga, peran guru dalam hal tersebut sangatlah penting guna menciptakan suasana belajar yang mampu mendukung siswa untuk berpikir analisis, yaitu dengan menerapkan model pembelajaran yang bervariasi. Senada dengan Suryanda, dkk (2016: 37-44) yang mengatakan bahwa peranan guru sangatlah penting guna mengarahkan siswa agar dapat berpikir analisis dalam proses pembelajaran. Salah satu kendala yang dialami guru untuk dapat mengembangkan kemampuan berpikir analisis siswa diantaranya karena model pembelajaran yang selama ini diterapkan masih kurang sesuai.

Saat ini, model pembelajaran yang digunaakan guru saat penyampaian materi membuat siswa kurang bersemangat untuk belajar, sehingga siswa terkesan kurang memperhatikan guru dalam pembelajaran. Komunikasi antara guru dengan siswa juga masih kurang. Ketika guru bertanya, 70\% siswanya kurang antusias untuk menjawab atau berpendapat. Bahkan tidak ada satupun siswa yang ingin bertanya ketika diberikan kesempatan untuk bertanya. Hasil wawancara dengan guru mata pelajaran IPA, diperoleh informasi bahwa dalam pembelajaran biologi siswa mengalami kesulitan untuk memahami materi ajar pemanasan global, serta siswanya kurang termotivasi untuk belajar. Sehingga, siswa juga tidak terlatih untuk mengembangkan kemampuan berpikir analisisnya. Padahal, pemanasan global merupakan salah satu materi IPA yang didalamnya memuat permasalahan yang menuntut siswa untuk memecahkan masalah secara global.

Pemananan global digambarkan dengan peningkatan secara bertahap suhu rata-rata atmosfer Bumi dan lautan, yang secara permanen mengubah iklim Bumi (Widodo, 2016: 74). Kompetensi dasar (KD) materi pemanasan global adalah KD 3.9 menganalisis perubahan 
iklim dan dampaknya bagi ekosistem. Berdasarkan Kurikulum 2013 sub topik yang mencakup materi pemanasan global adalah efek rumah kaca, pemanasan global beserta penyebabnya, dampak pemanasan global serta usaha-usaha untuk menanggulanginya.

Kesulitan siswa untuk mencapai kompetensi dasar materi tersebut karena menuntut siswa untuk mampu menganalisis permasalahan yang berkaitan dengan pemanasan global. Padahal nyatanya selama ini metode pembelajaran yang digunakan guru kurang mampu melatih siswa agar terbiasa berpikir secara analisis ataupun mengemukakan ide-idenya saat pembelajaran berlangsung. Sehingga siswa tidak memiliki gairah atau semangat untuk memahami materi ajar, yang menyebabkan hasil belajarnya rendah. Hal tersebut diperkuat dengan informasi yang di sampaikan guru bahwa hasil belajar untuk kelas VII pada materi pemanasan global tahun pelajaran 2017/2018 lebih dari 50\% berada dibawah kriteria ketuntasan minimum (KKM) yaitu 75,00. Dengan adanya situasi pembelajaran tersebut, perlu adanya tindakan yang harus dilakukan terhadap proses pembelajaran dikelas VII B, sehingga motivasi intrinsik siswa meningkat dan nantinya juga akan meningkatkan kemampuan kognitif level analisis siswa.

Motivasi intrinsik siswa dapat meningkat dengan menerapkan suatu model pembelajaran yang melibatkan siswa secara aktif belajar dalam kelompok, yang harapannya siswa terbantu dalam memahami materi sehingga mengoptimalkan kemampuan kognitif level analisisnya, yaitu melalui penerapan model pembelajaran group investigation (GI). Suprijono, A (2015: 112) menyatakan bahwa model pembelajaran group investigation merupakan salah satu tipe dari model pembelajaran kooperatif yang membentuk siswa dalam kelompok heterogen untuk belajar bersama dan menyelesaikan suatu masalah yang ditugaskan oleh guru kepada siswa. Sedangkan Nadiya, dkk (2016: 49-51) berpendapat GI merupakan suatu model pembelajaran yang menuntut siswa berpartisipasi aktif didalam kelompok kecil dan bersama kelompoknya mencari informasi terkait materi pembelajaran.

Group Investigation (GI) merupakan salah satu tipe pembelajaran kooperatif yang paling komplek. Pada dasarnya model ini dirancang untuk membimbing para siswa mendefinisikan masalah, mengeksplorasi mengenai masalah itu, mengumpulkan data yang relevan, mengembangkan dan menguji hipotesis (Primarinda,.dkk, 2012).

Group Investigation dalam pelaksanaannya menekankan siswa untuk aktif yaitu dengan learning by doing atau belajar dengan melakukan, pembelajaran yang berdasarkan prinsip motivasi dari dalam individu setiap siswa, sehingga timbulnya niat dan pengalaman yang diperoleh siswa dari pembelajaran dalam membentuk konsep pengetahuan yang kemudian akan berkembang memunculkan suatu nilai (Richvana,.dkk, 2012). 
Model pembelajaran group investigation, membuat siswa akan lebih termotivasi untuk berbuat sesuatu yang baik dan produktif saat siswa dihadapkan pada masalah yang terkait dengan kehidupan mereka sehari-hari. Untuk memecahkan suatu permasalahan siswa harus mampu menganalisis dan memahami konsep. Hal ini akan memberi arah kepada siswa untuk mengidentifikasi apa yang perlu diketahui dan dipelajari untuk dapat memahami konsep dan memecahkan masalah, serta merancang investigasi dan mengidentifikasi sumbersumber belajar yang diperlukan. Saat proses pemahaman konsep, siswa yang belajar secara aktif, baik aktif dalam berpikir (minds-on) dan aktif dalam berbuat (hands-on), bersama kelompok belajarnya akan memberikan kesempatan kepada setiap individu untuk dapat terlibat dalam proses berpikir dan kegiatan belajar (Suartika.,dkk, 2013).

Ada banyak hasil penelitian yang relevan sebelumnya mengenai model pembelajaran group investigation (GI) yang serupa dengan penelitian ini diantaranya penelitian Zulfiani, dkk (2016: 56-57) dengan judul "Peningkatan Motivasi Peserta Didik melalui Metode Group Investigation di MTs Negeri 1 Kota Tangerang Selatan" dengan hasil penelitian menunjukkan adanya peningkatan motivasi. Selain itu juga penelitian Mas'ud, Asrianty (2018: 43-47) dengan judul "Peningkatan Hasil Belajar Biologi Siswa melalui Penerapan Model Pembelajaran Kooperatif Tipe Group Investigation" dengan hasil penelitian menunjukkan bahwa terjadi peningkatan hasil belajar biologi siswa dari siklus I hingga siklus II. Berikutnya, penelitian dari Nasution, Halimah Fitri (2017: 28-33) dengan judul "Peningkatan Hasil Belajar Biologi Siswa melalui Penerapan Model Pembelajaran Kooperatif Tipe Group Investigation" dengan hasil penelitian tersebut menunjukkan terjadi peningkatan mulai dari siklus I hingga siklus II.

Persamaan dari ketiga penelitian di atas adalah sama-sama dilaksanakan dalam dua siklus dengan menerapkan model GI. Terdapat enam tahapan pada model pembelajaran kooperatif tipe group investigation yang disampaikan Slavin (2011: 218-226), diantaranya; a. mengidentifikasi topik; b. perencanaan kooperatif; c. investigasi (penyelidikan); d. penyajian laporan akhir; e. presentasi, dan; f. evaluasi.

Perbedaan penelitian dari ketiganya yaitu selain lokasi, waktu pelaksanaan penelitian beserta materi biologinya, juga dari instrumen pengumpulan data beserta teknik analisis datanta. Pada penelitian pertama, dilaksanakan di SMA Negeri 1 Binamu dengan materi biologi tentang plantae dan animalia. Instrumen yang digunakan berupa lembar tes hasil belajar sebanyak 40 soal pilihan ganda dengan analisis datanya berupa analisis deskriptif. Penelitian kedua dilaksanakan di MAN 6 Kotanopon dengan materi biologi tentang 
ekosistem, dengan instrument berupa lembar observasi kegiatan guru, lembar observasi keaktifan siswa, dan tes. Analisis datanya menggunakan uji T. Sedangkan untuk penelitian ketiga, dilaksanakan di MTs Negeri 1 Kota Tangerang Selatan, menggunakan instrumen pengum[ulan data berupa angket motivasi belajar siswa beserta lembar observasi aktivitas belajar, dengan analisis datanya menggunakan perhitungan skor total tiap indicator yang kemudian dirubah dalam persentase.

Perbedaan penelitian ini dengan penelitian di atas adalah pada langkah identifikasi topik peserta didik dengan memberikan kasus yang berkaitan dengan materi. Selain itu, motivasi belajar yang dilihat hanya pada motivasi intrinsik belajar siswa dan kemampuan kognitif level analisis. Materi pembelajaran yang digunakan adalah pemanasan global. Subjek penelitian yang akan diteliti adalah siswa kelas VII B SMP Negeri 2 Prambanan Sleman.

\section{METODE}

Jenis penelitian ini adalah penelitian tindakan kelas (PTK), terdiri atas empat komponen yang harus dilakukan, antara lain: 1) perencanaan (planning); 2) tindakan (action); 3) observasi (observing), dan; 4) refleksi (reflection). Subjek penelitian adalah siswa kelas VII B SMP Negeri 2 Prambanan Sleman tahun pelajaran 2018/2019 dan objek penelitiannya motivasi intrinsik, kemampuan kognitif level analisis dan model GI. Teknik pengumpulan data berupa observasi dan tes. Instrumen yang digunakan untuk mengumpulkan data berupa lembar observasi motivasi intrinsik belajar siswa, lembar observasi keterlaksanaan model GI dan soal post-test pilihan ganda. Ada 4 indikator yang digunakan pada lembar observasi motivasi intrinsik siswa, diantaranya; 1) tekun; 2) ulet menghadapi kesulitan; 3) kerja keras, dan; 4) kreatif dan inovatif. Sedangkan untuk lembar observasi keterlaksanaan pembelajaran sudah disesuaikan dengan sintak-sintak dari model pembelajaran GI. Instrumen soal post-test berbentuk pilihan ganda dengan jumlah 15 butir soal. Sebelum instrumen digunakan, terlebih dahulu harus dilakukan pengujian dengan tujuan mendapatkan data (mengukur) itu valid. Validitas yang digunakan untuk menguji instrumen tersebut adalah dengan menggunakan expert judgement. Analisis data menggunakan analisis deskriptif kuantitatif.

\section{HASIL DAN PEMBAHASAN}

Penelitian peningkatan motivasi intrinsik dan kemampuan kognitif level analisis melalui penerapan model pembelajaran group investigation (GI) pada materi pemanasan global siswa kelas VII B di SMP Negeri 2 Prambanan Sleman bertujuan untuk mengetahui penerapan 
model pembelajaran group investigation (GI) dapat terlaksana sesuai dengan sintak-sintak pembelajaran, serta besarnya persentase peningkatan motivasi intrinsik dan kemampuan kognitif level analisis siswa pada materi pemanasan global dari setiap siklus.

Group Investigation (GI) merupakan model pembelajaran yang mwmbuat siswa terlibat aktif sejak perencanaan, identifikasi topik hingga kegiatan penyelidikan atau investigasi. Kemampuan siswa berkomunikasi dalam kelompok sangat memegang peran penting ketika model ini diterapkan (Komalasari, 2011: 75).

Menurut Slavin (2011: 218-226) model GI terdiri dari enam tahapan, diantaranya; 1) mengidentifikasi topik; 2) perencanaan kooperatif; 3) investigasi (penyelidikan); 4) penyajian laporan akhir; 5) presentasi, dan; 6) evaluasi.

Berdasarkan data hasil observasi motivasi intrinsik belajar siswa diketahui bahwa penerapan model pembelajaran group investigation (GI) yang dilaksanakan di kelas VII B SMP Negeri 2 Prambanan Sleman pada kompetensi dasar 3.9 menganalisis perubahan iklim dan dampaknya bagi ekosistem tentang materi pemanasan global dapat meningkatkan motivasi intrinsik belajar siswa serta kemampuan kognitif level analisis. Peningkatan motivasi intrinsik belajar siswa ditunjukkan pada Tabel 1.

Tabel 1. Data Hasil Observasi Motivasi Intrinsik Belajar Siswa Siklus I dan II

\begin{tabular}{|c|c|c|c|c|c|}
\hline \multirow[b]{2}{*}{ No } & \multirow[b]{2}{*}{ Indikator } & \multicolumn{2}{|c|}{ Siklus I } & \multicolumn{2}{|c|}{ Siklus II } \\
\hline & & $\begin{array}{c}\text { Persentase } \\
(\%)\end{array}$ & Kriteria & $\begin{array}{c}\text { Persentase } \\
(\%)\end{array}$ & Kriteria \\
\hline 1. & Tekun & 57,14 & Sedang & 86,67 & Sangat tinggi \\
\hline 2. & $\begin{array}{l}\text { Ulet menghadapi } \\
\text { kesulitan }\end{array}$ & 25 & Rendah & 75 & Tinggi \\
\hline 3. & Kerja keras & 79,76 & Tinggi & 93,33 & Sangat tinggi \\
\hline 4. & Kreatif dan inovatif & 20,24 & $\begin{array}{l}\text { Sangat } \\
\text { rendah }\end{array}$ & 63,33 & Sedang \\
\hline & Rata-rata persentase & 45,53 & Sedang & 79,58 & Tinggi \\
\hline
\end{tabular}

Hasil Tabel 1 menunjukkan bahwa semua indikator mengalami peningkatan baik dari siklus I hingga siklus II. Persentase paling tinggi adalah indikator kerja keras yaitu siklus I dengan persentase $79,76 \%$ dan meningkat pada siklus II jadi 93,33\%. Kemudian, tekun merupakan indikator tertinggi kedua dengan persentase di siklus I sebesar 57,14\% meningkat pada siklus II menjadi 86,67\%. Sedangkan untuk ulet menghadapi kesulitan serta kreatif dan inovatif merupakan dua indikator yang persentasenya paling rendah baik dari siklus I maupun siklus II. Pada siklus I indikator ulet menghadapi kesulitan persentasenya sebesar 25\% meningkat pada siklus II jadi 75\%. Sedangkan persentase indikator kreatif dan inovatif siklus I sebesar 20,24\% kemudian meningkat jadi 63,33\% pada siklus II. Sehingga diketahui bahwa 
rata-rata persentase motivasi intrinsik siswa pada siklus I yaitu 45,53\% sedangkan pada siklus II meningkat jadi 79,58\%. Besarnya peningkatan persentase dari siklus I ke siklus II yaitu sebesar 34,05\%. Dari hasil tersebut menunjukkan bahwa pada siklus I belum mencapai indikator keberhasilan 60\%. Sedangkan pada siklus II sudah mencapai indikator keberhasilan 70\%. Hal ini dikarenakan pada siklus II siswa terlihat antusias, mulai aktif bertanya, serta dapat menyampaikan pendapat.

Adanya peningkatan yang signifikan pada keempat indikator motivasi intrinsik baik dari siklus I hingga siklus II disebabkan karena perbaikan-perbaikan yang telah dilakukan di siklus II. Agar terciptanya komunikasi dan kerja sama yang baik, guru lebih mengatur posisi duduk setiap kelompok agar dapat saling bertatap muka. Selain itu, guru juga mengulang penjelasan sintak-sintak dari model pembelajaran GI agar siswa lebih memahami tugas yang akan dilakukan sehingga masing-masing siswa mampu bertanggung jawab terhadap tugasnya masing-masing. Dengan adanya pengulangan penjelasan ini, harapannya siswa menjadi terbiasa dengan model pembelajaran GI. Sesuai dengan pernyataan Dimyati dan Moedjino (2015: 254) bahwa proses belajar siswa akan sangat dipengaruhi oleh biasa tidaknya siswa terhadap model pembelajaran yang diterapkan guru. Tugas guru sebagai fasilitator juga lebih dimaksimalkan yaitu dengan lebih sering berkeliling ke setiap kelompok, mengajukan pertanyaan pada setiap kelompok agar siswa antusias untuk menjawab dan mengemukakan ide-idenya didalam kelompoknya. Hal ini sependapat dengan pernyataan Djaali (2013: 109) bahwa ketika siswa sudah menyukai situasi pembelajaran menandakan bahwa siswa tersebut termotivasi untuk belajar. Sehingga dengan demikian siswa akan bertanggung jawab terhadap tugasnya selama proses pembelajaran berlangsung.

Senada dengan penelitian Zulfiani, dkk (2016: 56-57) yang berjudul Peningkatan Motivasi Peserta Didik Melalui Metode Group Investigation di MTs Negeri 1 Kota Tangerang Selatan. Hasil dari penelitian tersebut menunjukkan adanya peningkatan motivasi. Hasil penelitian yang serupa Fitri dan Susilo (2013: 1-96) juga dilaporkan bahwa terjadi peningkatan motivasi belajar biologi siswa dalam mengikuti kegiatan pembelajaran baik pada siklus I maupun siklus II. Selain itu penelitian Laila, dkk (2013: 2016) juga menunjukkan hasil bahwa motivasi belajar siswa meningkat setelah menerapkan model pembelajaran group investigation, baik dari siklus I hingga siklus II. 
Tabel 2. Hasil Post-Test Siswa Siklus I dan II

\begin{tabular}{|c|c|c|c|c|c|}
\hline \multirow[b]{2}{*}{ No } & \multirow[b]{2}{*}{ Perolehan nilai } & \multicolumn{2}{|c|}{ Siklus I } & \multicolumn{2}{|c|}{ Siklus II } \\
\hline & & Jumlah siswa & $\begin{array}{c}\text { Persentase } \\
(\%)\end{array}$ & Jumlah siswa & $\begin{array}{c}\text { Persentase } \\
(\%)\end{array}$ \\
\hline 1. & $<75$ & 16 & 57,14 & 5 & 16,67 \\
\hline 2. & $>75$ & 12 & 42,86 & 25 & 83,33 \\
\hline & Rata-rata nilai & \multicolumn{2}{|c|}{72,14} & \multicolumn{2}{|c|}{84,22} \\
\hline
\end{tabular}

Adanya peningkatan motivasi intrinsik belajar siswa akan berdampak terhadap hasil belajar kemampuan kognitifnya. Pada penelitian ini hasil belajar yang dimaksud adalah kemampuan kognitif level analisis siswa. Berdasarkan hasil diatas dapat dilihat bahwa terjadi peningkatan rata-rata nilai post-test (mencakup level ingatan, pemahaman, aplikasi dan analisis) dari siklus I sebesar 72,14 menjadi 84,22 pada siklus II. Besarnya peningkatan persentase dari siklus I ke siklus II yaitu sebesar 12,08\%. Pada pembelajaran siklus I dengan menggunakan model pembelajaran group investigation (GI), hasil belajar siswa belum mencapai hasil yang memuaskan. Hal ini dilihat dari tabel 2 sebelumnya, bahwa jumlah siswa yang tuntas adalah 12 siswa dengan persentase 42,86\% sedangkan sisanya 16 siswa belum tuntas dengan persentase $57,14 \%$. Hasil tersebut belum mencapai indikator keberhasilan yaitu pada siklus I nilai rata-rata post-test $60 \%$ siswa mencapai kriteria ketuntasan minimal (KKM) yaitu 75,00. Sedangkan pada siklus II jumlah siswa yang tuntas adalah 25 siswa dengan persentase $83,33 \%$ sisanya 5 siswa belum tuntas dengan persentase $16,67 \%$. Hasil tersebut sudah mencapai indikator keberhasilan yaitu pada siklus II nilai ratarata post-test $70 \%$ siswa mencapai kriteria ketuntasan minimal (KKM) yaitu 75,00.

Tabel 3. Data Hasil Kemampuan Kognitif Level Analisis Siswa Siklus I dan II

\begin{tabular}{cccc}
\hline \multirow{2}{*}{ No } & Kemampuan kognitif & Siklus I & Siklus II \\
\cline { 3 - 4 } & Persentase (\%) & Persentase (\%) \\
\hline 1. & Ingatan (C1) & 77,38 & 100 \\
2. & Pemahaman (C2) & 78,58 & 80,67 \\
3. & Aplikasi (C3) & 66,67 & 92,22 \\
4. & Analisis (C4) & 69,90 & 80,56 \\
& Jumlah rata-rata & 73,13 & 88,36 \\
\hline
\end{tabular}

Sedangkan untuk kemampuan kognitif level analisis siswa pada siklus I penguasaan siswa terhadap soal analisis adalah $69,90 \%$ dan siklus II $80,56 \%$ sehingga meningkat $10,66 \%$. Hasil tersebut sudah mencapai indikator keberhasilan yaitu pada siklus I kemampuan kognitif level analisis siswa meningkat $60 \%$ dan pada siklus II meningkat $70 \%$.

Adanya peningkatan motivasi intrinsik siswa sangat berpengaruh terhadap peningkatan hasil post-test dan penguasaan kemampuan kognitif level analisis siswa. Rendahnya motivasi intrinsik belajar siswa pada siklus I berdampak ke hasil belajar 
kemampuan kognitif yang kurang maksimal. Ketika motivasi intrinsik belajar siswa meningkat pada siklus II, maka terjadi pula peningkatan hasil belajar kemampuan kognitif siswa. Sehingga dapat disimpulkan jika motivasi intrinsik belajar siswa tinggi maka hasil belajar dari kemampuan kognitifnya juga tinggi. Hal ini sesuai dengan yang diungkapkan Widoyoko (2014: 233) bahwa keberhasilan proses dan hasil belajar sangat dipengaruhi kuat oleh motivasi belajar siswa. Salah satu indikator kualitas pembelajaran adalah adanya semangat maupun motivasi belajar pada diri siswa yang dicerminkan dengan indikator kerja keras siswa ketika mengerjakan tugas-tugasnya selama proses pembelajaran berlangsung. Selain itu, hasil penelitian Listiana, Lina (2013) melaporkan bahwa model pembelajaran kooperatif tipe group investigation (GI) merupakan model pembelajaran yang efektif dan berpotensi untuk memberdayakan keterampilan bepikir siswa dalam proses pembelajaran biologi.

Penelitian serupa oleh Mas'ud, Asrianty (2018: 43-47) menunjukkan bahwa terjadi peningkatan hasil belajar biologi siswa dari siklus I ke siklus II. Selain itu juga diperkuat penelitian Nasution, Halimah Fitra (2017: 28-33) dengan judul Peningkatan Hasil Belajar Biologi Siswa Melalui Penerapan Model Pembelajaran Kooperatif Tipe Group Investigation. Hasil dari penelitian tersebut menunjukkan bahwa terjadi peningkatan mulai dari siklus I hingga siklus II.

Tabel 4. Data Keterlaksanaan Model GI Siswa Kelas VII B SMP Negeri 2 Prambanan Sleman Siklus I dan II

\begin{tabular}{cccc}
\hline \multirow{2}{*}{ No } & Kegiatan & Siklus I & Siklus II \\
\cline { 3 - 4 } & Persentase (\%) & Persentase (\%) \\
\hline 1. & Membuka pelajaran & 90,18 & 99,17 \\
2. & Identifikasi topik & 91,67 & 100 \\
3. & Perencanaan kooperatif & 87,50 & 93,34 \\
4. & Penyelidikan/investigasi & 82,15 & 93,34 \\
5. & Laporan akhir & 80,36 & 98,34 \\
6. & Presentasi & 78,57 & 80 \\
7. & Evaluasi & 94,05 & 100 \\
& Jumlah rata-rata & 86,35 & 94,88 \\
\hline
\end{tabular}

Adanya peningkatan motivasi intrinsik dan kemampuan kognitif level analisis juga diperkuat dengan data hasil observasi keterlaksanaan pembelajaran dengan menerapkan model pembelajaran GI. Pada siklus I, besar persentase keterlaksanaan pembelajarannya yaitu 86,53\% dengan kategori baik, meningkat di siklus II jadi 94,88\% dengan kategori sangat baik. Sehingga, peningkatan keterlaksanaan pembelajaran dari siklus I ke siklus II adalah sebesar $8,53 \%$. Pada siklus I, model GI sudah terlaksana dengan baik, hanya saja belum optimal keterlaksanaannya yaitu pada kegiatan perencanaan koperatif $87,50 \%$, investigasi 
$82,15 \%$, penyusunan laporan akhir $80,36 \%$ dan presentasi $78,57 \%$. Keempat sintak tersebut berada dalam kategori baik, artinya belum terlaksana secara optimal (belum mencapai kategori sangat baik). Hal tersebut disebabkan karena pada waktu proses pembelajaran berlangsung, masih banyak siswa yang kurang paham terhadap sintak dari model GI, sehingga menyebabkan siswa kurang bertanggung jawab terhadap tugasnya didalam kelompok. Sehingga pada penyusunan laporan akhir, masih banyak siswa yang kurang bekerja sama dalam menyusun laporan, melainkan ada beberapa kelompok yang mengerjakannya secara individu. Selain itu juga, pengkondisian tempat duduk kelompok yang kurang baik, menyebabkan kerjasama siswa dengan kelompoknya menjadi tidak maksimal. Sehingga ketika presentasi kelompok, banyak kelompok yang masih kurang memperhatikan kelompok lain yang sedang presentasi didepan kelas. Selain itu, masih ditemukan siswa yang enggan untuk mempresentasikan hasil investigasi kelompoknya. Hasil temuan tersebutlah yang kemudian menjadi bahan refleksi peneliti untuk melakukan perbaikan pada siklus II sehingga keterlaksanaan pembelajaran di siklus II meningkat terutama pada kegiatan perencanaan kooperatif (93,34\% dengan kategori sangat baik), investigasi (93,34\% dengan kategori sangat baik), penyusunan laporan akhir (98,34\% dengan kategori sangat baik) dan presentasi (80\% dengan baik).

Perbaikan-perbaikan yang dilakukan peneliti guna dapat meningkatkan motivasi intrinsik dan kemampuan kognitif level analisis siswa yaitu terletak pada terlaksananya pembelajaran yang sesuai dengan sintak-sintak model pembelajaran GI. Jika keterlaksanaan pembelajaran dapat terlaksana sesuai dengan sintak-sintak model pembelajaran GI, maka motivasi intrinsik belajar siswa akan meningkat, dan hasil dari kemampuan kognitif analisis siswa pun juga meningkat. Hal tersebut sejalan dengan penelitian yang dilakukan oleh Leonardos dan Siregar (2014: 2) bahwa keberhasilan model pembelajaran kooperatif tipe group investigation berfokuskan pada proses keterlibatan siswa secara penuh untuk dapat menemukan materi yang dipelajari yang nantinya dihubungkan pada situasi kehidupan nyata sehingga siswa terdorong untuk dapat menerapkannya di kehidupan sehari-hari. Sehingga dalam proses pembelajaran group investigation siswa tidak hanya berperan sebagai penerima pelajaran melainkan jugasiswa menemukan sendiri inti dari materi pelajaran.

Ketika siswa diberikan kesempatan untuk berpikir secara analisis, kreatif dan inovatif, saling membantu satu sama lain dengan tekun, ulet, dan bekerja keras dalam menyelesaikan permasalahan ataupun dalam menguasai materi pembelajaran yang sedang dipelajari, maka siswa akan mampu memahami dan menganalisis materi pembelajaran 
dengan mudah. Dengan demikian siswa akan memiliki kemampuan kognitif level analisis yang baik. Berdiskusi dalam kelompok merupakan langkah penting dalam menganalisis kasus karena di dalam kelompok diskusi siswa dapat lebih mudah bertukar pendapat dalam memecahkan permasalahan yang ada pada kasus. Hal ini sependapat dengan pernyataan Slavin (2011:218-226) ketika para siswa bekerja sama untuk mencapai tujuan yang sama, seperti yang mereka lakukan secara aktif pada proses awal identifikasi, investigasi hingga menghasilkan laporan akhir dan mempresentasikannya, mereka belajar berusaha untuk dapat membantu keberhasilan teman satu kelompoknya. Oleh sebab itu, para siswa saling mendorong satu sama lain dalam pembelajaran, kemudian mengekspresikannya sesuai dengan pencapaiannya dipembelajaran. Seperti yang dikemukakan Sutama (2007) dalam jurnal Artini dkk (2015: 2) bahwa model pembelajaran group investigation merupakan pembelajaran berbasis kelompok yang memberikan peluang kepada siswa untuk berdiskusi, berpikir analisis, dan dapat bertanggung jawab dalam pembelajaran tersebut.

Proses penerapan pembelajaran menggunakan model pembelajaran group investigation berjalan dengan baik sesuai dengan sintak-sintak pembelajaran. Model pembelajaran ini membuat suasana yang menyenangkan bagi siswa, secara aktif siswa mampu memecahkan masalah dengan baik tanpa putus asa sehingga memotivasi siswa untuk belajar (Faujiyah dkk, 2017: 1). Dibandikan dengan siklus I, dalam hal ini siswa mulai terampil dalam menganalisis kasus, lebih antusias dalam belajar, berani berpendapat dan mengajukan pertanyaan pada guru.

Peningkatan nilai post-test siswa pada siklus II menunjukkan bahwa usaha perbaikan proses pembelajaran biologi dengan penerapan model pembelajaran group investigation (GI) berjalan dengan baik dilihat dari rata-rata nilai post-test siswa. Oleh karena itu, pelaksanaan tindakan kelas dihentikan pada siklus II. Sehingga penerapan model pembelajaran group investigation (GI) pada materi pembelajaran pemanasan global dapat dikatakan telah berhasil untuk meningkatkan kemampuan kognitif level analisis siswa kelas VII B SMP Negeri 2 Prambanan Sleman tahun ajaran 2018/2019.

\section{SIMPULAN}

Berdasarkan hasil penelitian dan pembahasan yang telah diuraikan sebelumnya dapat disimpulkan bahwa penerapan model pembelajaran group investigation (GI) pada materi pemanasan global di kelas VII B SMP Negeri 2 Prambanan Sleman tahun ajaran 2018/2019 dapat terlaksana sesuai sintak-sintaknya yaitu identifikasi topik, perencanaan kooperatif, 
penyelidikan (investigasi), penyajian laporan akhir, presentasi dan kemudian diakhiri dengan evaluasi. Hasil penelitian juga menunjukkan bahwa pada setiap siklus pembelajaran pada materi pemanasan global melalui penerapan model pembelajaran group investigation (GI) mengalami peningkatan motivasi intrinsik dan kemampuan kognitif level analisis siswa. Pada siklus I rata-rata motivasi intrinsik belajar siswa 45,53\% meningkat pada siklus II menjadi rata-rata 79,58\% . Rata-rata nilai post-test siswa ( mencakup level ingatan, pemahaman, aplikasi hingga analisis) pada siklus I yaitu 72,14 meningkat pada siklus II menjadi 84,22. Sedangkan kemampuan level analisis siklus I 69,90\% dan 80,56\% pada siklus II.

\section{REFERENSI}

Abdurrahman, Mulyono. 2012. Anak Berkesulitan Belajar. Jakarta: Rineka Cipta.

Anderson, Lorin W. \& Krathwohl, David R. 2010. Kerangka Landasan untuk Pembelajaran, Pengajaran, dan Asesmen (Edisi Revisi). Yogyakarta: Pustaka Pelajar.

Artini, dkk. 2015. Penerapan Model Pembelajaran Kooperatif Tipe Group Investigation Untuk Meningkatkan Aktivitas dan Hasil Belajar IPA pada Siswa Kelas VI Tondo. Jurnal Mitra Sains. Mahasiswa Program Studi Magister Pendidikan Sains Pascasarjana Universitas Tadulako dan Staf Pengajar Program Studi Magister Pendidikan Sains Pascasarjana Universitas Tadulako. Vol III. Nomor 1. Halaman: 4552. ISSN: 2302-2027.

Dimyati dan Mudjiono. 2015. Belajar dan Pembelajaran. Jakarta: Rineka Cipta.

Djaali. 2013. Psikologi Pendidikan. Jakarta: PT Bumi Aksara.

Faujiyah, dkk. 2018. Penerapan Model Pembelajaran Group Investigation Terhadap Hasil Belajar Siswa Pada Materi Sistem Ekskresi Manusia. Bioedukatika. Vol VII. Nomor 1. ISSN : 2338-7173.

Fitri, Efi Solina \& Susilo, Muhammad Joko. 2013. Peningkatan Motivasi Belajar Biologi Siswa Kelas X.3 Melalui Model Group Investigation (Gi) Pada Materi Avertebrata Di Sma Negeri I Pajangan Tahun Ajaran 2011/2012. Bioedukatika UIN. Vol VII. Nomor 1. ISSN : $1-96$.

Komalasari, K. 2011. Pembelajaran Kontekstual: Konsep dan Aplikasi. Bandung: Refika Aditama.

Laila, dkk. 2016. Meningkatkan Motivasi Belajar Siswa Pada Pembelajaran IPS Menggunakan Model Pembelajaran Kooperatif Tipe Group Investigation. Jurnal Teori dan Praksis Pembelajaran IPS. Vol. I. Nomor 2. P-ISSN 2503-1201. E-ISSN 2503-5347.

Leonardus, Salomo dan Siregar, Nurdin 2014. Pengaruh Model Pembelejaran Kooperatif Tipe Group Investigation terhadap Hasil Belajar pada Materi Listrik Dinamis.Jurnal Inpafi. Prodi Pendidikan Fisika FMIPA Universitas Negeri Medan. Vol II. Nomor 2.

Listiana, Lina. 2013. Pemberdayaan Keterampilan Berpikir dalam Pembelajaran Biologi Melalui Model Kooperati Tipe GI (Group Investigation) dan TTW (Think, Talk, Write). Proceeding Biology Education Conference: Biology, Science, Enviromental, and Learning. Vol X. Nomor 1. 
Mas'ud, Asrianty. 2018. Peningkatan Hasil Belajar Biologi Siswa Melalui Penerapan Model Pembelajaran Kooperatif Tipe Group Investigation. Bioedukatika UIN. Vol VIII. Nomor 1. Hal: 43-47.

Nadiya, dkk. 2016. Penerapan Model Pembelajaran Group Investigation (GI) untuk Meningkatkan Keterampilan Berpikir Kritis Siswa pada Materi Gerak Lurus Kelas X. Jurnal Ilmu Pendidikan Fisika. Vol I. Nomor 2. Halaman: 49-5. ISSN: 2477-8451.

Nasution, Halimah Fitra. 2017. Peningkatan Hasil Belajar Biologi Siswa Melalui Penerapan Model Pembelajaran Kooperatif Tipe Group Investigation (GI). Peteka (Penelitian Tindakan Kelas dan Pengembangan Pembelajaran). Vol I. Nomor 1. Hal: 28-33.

Primarinda, Ikha., dkk. 2012. Pengaruh Model Pembelajaran Cooperative Learning Tipe Group Investigation (GI) Terhadap Keterampilan Proses Sains dan Hasil Belajar Biologi Siswa Kelas X SMA N 4 Surakarta Tahun Pelajaran 2011/2012. Jurnal Pendidikan Biologi FKIP UNS. Vol IV. Nomor 2.

Richvana, B., dkk. Pengaruh Model Pembelajaran Group Investigation Terhadap Hasil Belajar Biologi Ditinjau dari Tingkat Kreativitas Siswa Kelas X SMAN 2 Karanganyar. Jurnal Pendidikan Biologi FKIP UNS. Vol IV. Nomor 1.

Sardiman, A.M. 2016. Interaksi dan Motivasi Belajar Mengajar. Jakarta: Rajawali Press.

Slavin, E. Robert. 2011. Cooperative Learning: Teori, Riset dan Praktik. Bandung: Nusa Media.

Suartika, dkk. 2013. Pengaruh Model Pembelajaran Kooperatif Tipe Group Investigation (GI) Terhadap Pemahaman Konsep Biologi dan Keterampilan Berpikir Kreatif Siswa SMA. E-Journal Program Pascasarjana Universitas Pendidikan Ganesha. Vol.III

Sukimarwati, Juli., dkk. 2013. Pembelajaran Biologi dengan Guided Inquiry Model Menggunakan LKS Terbimbing dan LKS Bebas Termodifikasi Ditinjau dari Kreativitas dan Motivasi Berprestasi Siswa. Bioedukasi. Volume VI. Nomor 2. Halaman: 46-57. ISSN 1693-2654.

Suprijono, Agus. 2015. Cooperative Learning. Yogyakarta: Pustaka Pelajar.

Suryanda, dkk. 2016. Pengaruh Penerapan Model Pembelajaran Group Investigation (GI) Terhadap Kemampuan Berpikir Analisis Siswa Pada Materi Pencemaran Lingkungan. BIOSFERJPB. Vol. IX. Nomor 2. Hal: 37-44. ISSN: 0853-2451.

Susanto, Ahmad. 2011. Perkembangan Anak Usia Dini. Jakarta: Kencana Prenada.

Uno, Hamzah. 2012. Teori Motivasi dan Pengukurannya (Analisis di Bidang Pendidikan). Jakarta: PT Bumi Aksara.

Widodo, Wahono.,dkk. 2016. Ilmu Pengetahuan Alam untuk SMP/MTs Kelas VII Semester 2. Jakarta: Kemendikbud.

Widoyoko. 2014. Penilaian Hasil Pembelajaran di Sekolah. Yogyakarta: Pustaka Pelajar.

Zulfiani., dkk. 2016. Peningkatan Motivasi Belajar Peserta Didik Melalui Metode Group Investigation di MTs Negeri 1 Kota Tangerang Selatan. Seminar Nasional Pendidikan IPA-Biologi UIN. ISBN 978-602-73551-0-8. 